\title{
Analisis Budaya Kaizen dan Keterlibatan Kerja dengan Komitmen Organisasi sebagai Intervening terhadap Prestasi Kerja Karyawan (Studi Empiris pada PT. Gloria Jaya Sejahtera Medan)
}

\author{
Abd. Rasyid Syamsuri \\ Sekolah Tinggi Ilmu Ekonomi Labuhan Batu Rantau Prapat Sumatera Utara \\ e-mail: abd.rasyidsyamsuri@gmail.com
}

\begin{abstract}
Abstrak
Penelitian ini bertujuan untuk menganalisis pengaruh budaya kaizen, keterlibatan kerja dan komitmen organisasi sebagai intervening terhadap prestasi kerja karyawan. Responden adalah para karyawan PT. Gloria Jaya Sejahtera Medan sebanyak 40 orang dengan pengambilan sampel menggunakan sensus (sampel jenuh). Sumber data primer diperoleh secara langsung melalui wawancara dan kuesioner. Teknik analisis data menggunakan SEM (Stuctural Equation Modelling) dengan program SmartPLS. Hasil Path Coefficients menunjukkan bahwa budaya kaizen berpengaruh positif dan tidak signifikan terhadap komitmen organisasi; keterlibatan kerja berpengaruh positif dan signifikan terhadap komitmen organisasi; budaya kaizen berpengaruh positif dan signifikan terhadap prestasi kerja karyawan; keterlibatan kerja berpengaruh positif dan signifikan terhadap prestasi kerja karyawan; serta, komitmen organisasi berpengaruh positif dan tidak signifikan terhadap prestasi kerja karyawan.
\end{abstract}

Kata kunci: Kaizen, keterlibatan kerja, komitmen organisasi, prestasi kerja.

\section{PENDAHULUAN}

Manajemen berhubungan dengan suatu usaha untuk mencapai sasaran-sasaran tertentu dengan jalan menggunakan sumbersumber yang telah tersedia dengan sebaikbaiknya, sumber yang paling penting dalam setiap organisasi adalah sumber daya manusia (SDM), (Syamsuri, 2012). Sumber Daya Manusia merupakan salah satu elemen utama yang menempati posisi sangat strategis dalam organisasi atau perusahan. Artinya, unsur manusia memegang peranan sangat penting dalam menjalankan aktivitas guna pencapaian tujuan.

Untuk itu masalah sumber daya manusia merupakan masalah yang penting dari keseluruhan tingkat perencanaan sampai dengan evaluasi yang memanfaatkan sumber daya manusia itu. Hal ini termasuk dalam mewujudkan budaya kaizen, keterlibatan kerja dan komitmen organisasi terhadap prestasi kerja yang dilakukan para anggota organisasinya dalam pencapaian tujuan yang telah ditetapkan. Tujuan ini dapat dicapai apabila organisasi didukung oleh sumber daya manusia yang baik, memiliki performa kerja yang tinggi dan sumber daya manusia yang berkompeten di dalam pekerjaan.

PT Gloria Jaya Sejahtera Medan merupakan Perusahaan yang bergerak dalam bidang retail atau hypermarket yang menjual segala kebutuhan sehari-hari. Barang-barang yang dijual di hypermarket ini adalah barangbarang kebutuhan sehari hari, seperti bahan makanan, minuman, dan barang kebutuhan lainnya. PT Gloria Jaya Sejahtera Medan mempunyai tujuan untuk mengembangkan usahanya, mempertahankan hidup, dan menghasilkan laba, sebagai alat ukur keberhasilan dalam menjalankan usaha. Untuk meningkatkan keunggulan sumber daya manusia pada perusahaan, budaya kaizen, keterlibatan kerja dan komitmen organisasi perlu dipertimbangkan sebagai hal yang mendasar dalam mendorong prestasi kerja karyawan. 
Prestasi kerja dapat diukur sebagai tingkat keberhasilan karyawan di dalam menyelesaikan pekerjaannya. Prestasi kerja bukan karakteristik individu, seperti bakat atau kemampuan, namun lebih merupakan perwujudan dari bakat atau kemampuan itu sendiri. Perwujudan prestasi kerja dapat dilihat dari kemampuan dalam bentuk nyata. Prestasi kerja juga sebagai hasil kerja yang dicapai karyawan dalam mengemban tugas atau pekerjaan yang berasal dari organisasi. Para karyawan dituntut untuk dapat melaksanakan tugas yang dibebankan agar lebih profesional, yang berarti karyawan mempunyai pandangan untuk selalu berpikir, kerja keras, bekerja sepenuh waktu, jujur, memiliki loyalitas tinggi dan penuh dedikasi demi keberhasilan perkerjaannya.

Budaya organisasi adalah nilai-nilai, prinsip-prinsip, tradisi, dan cara-cara bekerja yang dianut bersama oleh para anggota organisasi serta mempengaruhi cara mereka dalam melakukan tindakan (Robbins \& Coulter, 2010). Budaya organisasi terkait dengan cara bekerja yang dianut secara bersama-sama oleh semua anggota organisasi dan tidak bisa dipisahkan dengan aktivitas SDM. New Shorter Oxford English Dictionary (1993) mengenali kata 'kaizen' sebagai kata bahasa Inggris yang mendefinisikan 'kaizen' sebagai perbaikan terus menerus dari praktik kerja, dan efisiensi pribadi, sebagai filosofi bisnis.

Kaizen juga dapat dikatakan sebagai budaya. Dalam bahasa Jepang, 'kaizen' berarti perbaikan terus-menerus. Pernyataan ini mengandung arti yang tertuju pada peningkatan SDM baik manajer maupun karyawan yang berfokus pada upaya-upaya perbaikan perusahan untuk mencapai keberhasilan. Imai (2012) menyatakan bahwa kaizen memiliki kontribusi besar terhadap keberhasilan kompetitif jepang. Dengan demikian, penelitian ini menganalisis apakah ada upaya yang dilakukan PT Gloria Jaya Sejahtera Medan untuk menerapkan proses perbaikan terus-menerus dari praktik kerja para karyawan.

Budaya Kaizen dapat meningkatkan pengelolaan sistem manajemen, dan standar operasional yang ada sekaligus menjaga standar tersebut dengan tujuan agar semua karyawan dapat mematuhi prosedur pengoperasian standar yang telah ditetapkan. Kaizen memperbaiki dan meningkatkan standar-standar yang ditetapkan perusahaan. Berdasarkan hasil observasi di PT Gloria Jaya Sejahtera Medan, standar operasional sering mengalami perubahan sehingga relevansi, kekuratan dalam operasionalisasi pekerjaan, ketepatan waktu, dan efisiensi pekerjaan tidak terlaksana dengan baik. Perubahan prosedur operasionalisasi ini menyebabkan karyawan menjadi kurang efektif dalam menyelesaikan pekerjaan.

Menurut Robbins dan Coulter (2010), keterlibatan kerja merupakan derajat dimana seorang karyawan mengidentifikasi pekerjaannya, secara aktif berpartisipasi di dalamnya, dan menganggap performa kerja nya sebagai hal penting dalam menghargai dirinya. Karyawan dengan keterlibatan kerja yang tinggi sangat mengidentifikasi dan sangat peduli terhadap jenis pekerjaan yang mereka lakukan. Dari hasil observasi dan survey yang dilakukan di PT Gloria Jaya Sejahtera Medan, keterlibatan kerja karyawan belum sepenuhnya terlaksana dengan baik. Hal ini dilihat dari karyawan yang tidak tepat waktu sewaktu masuk kerja, dan ketidakhadiran karyawan untuk melaksanakan tugas atau pekerjaannya. Keterlibatan kerja seharusnya mendorong peningkatan pencapian tujuan bagi suksesnya suatu organisasi atau perusahaan.

Faktor lain yang dapat mempengaruhi prestasi kerja adalah komitmen organisasi. Pengertian komitmen saat ini, memang tak lagi sekedar berbentuk kesediaan karyawan menetap di perusahaan itu dalam jangka waktu lama. Namun lebih penting dari itu, mereka mau memberikan yang terbaik kepada perusahaan, bahkan bersedia mengerjakan sesuatu melampaui batas yang diwajibkan perusahaan. Hal Ini, tentu saja, hanya bisa terjadi jika karyawan merasa senang dan terpuaskan di perusahaan yang bersangkutan (Luthans, 2012). Komitmen organisasi menunjukkan sikap yang merefleksikan loyalitas karyawan pada organisasi dan proses keberlanjutan dimana anggota organisasi 
mengekspresikan perhatian dirinya kepada organisasi dan keberhasilan serta kemajuan yang berkelanjutan.

Karyawan yang menunjukkan komitmen tinggi memiliki keinginan untuk memberikan tanggung jawab yang lebih, ketersediaan karyawan untuk bekerja keras dalam upaya mendukung keberhasilan perusahaan. Hal ini yang menyebabkan kurangnya komitmen organisasi. Berdasarkan hasil dari survey yang dilakukan di PT Gloria Jaya Sejahtera Medan, terlihat adanya perilaku keorganisasian negatif, yaitu adanya karyawan yang meninggalkan jam kerja. Rendahnya tingkat komitmen tersebut mencerminkan kurangnya tanggungjawab seseorang dalam menjalankan tugasnya. Oleh sebab itu, aspek komitmen organisasi memiliki peranan yang penting untuk keberlangsungan tujuan perusahaan.

Sumber daya manusia berperan aktif dalam meningkatkan prestasi kerja pada organisasi atau perusahaan, termasuk pada bagaimana mewujudkan budaya kaizen, keterlibatan kerja dan komitmen organisasi di PT Gloria Jaya Sejahtera Medan. Berdasarkan fenomena dan latar belakang permasalahan tersebut, penelitian ini membahas tentang pengaruh budaya kaizen, dan keterlibatan kerja dengan komitmen organisasi sebagai intervening terhadap prestasi kerja karyawan, dengan obyek penelitian pada PT. Gloria Jaya Sejahtera Medan.

Menurut McLoughlin dan Miura (2018), Kai berarti "berubah" dan Zen berarti "benar." Oleh karena itu, Kaizen berarti berubah ke arah menjadi lebih baik. Mereka juga mengemukakan bahwa kaizen berusaha untuk membawa hal-hal pada keadaan yang lebih baik. Kaizen juga sebagai filosofi daripada metodologi, dan karena itu kaizen merupakan benang merah yang dapat digunakan di seluruh fungsi dan proses bisnis apa pun. Perubahan yang dibuat tidak harus besar, tetapi tertuju pada perbaikan. Dengan pola pikir ini, kaizen akan membuat keadaan lebih baik dari keadaan saat ini atau masa lalu.

Pada penerapannya dalam perusahaan, Kaizen diartikan sebagai perbaikan terus menerus. Ciri kunci manajemen kaizen antara lain lebih memperhatikan proses dan bukan hasil, manajemen fungsional-silang, menggunakan lingkaran kualitas dan peralatan lain untuk mendukung peningkatan yang terus menerus (Imai, 2012). Lima komponen dalam konsep kaizen yang disebut sebagai 5-S meliputi: (1) Seiri, yaitu memisahkan benda yang diperlukan dengan yang tidak diperlukan, kemudian menyingkirkan yang tidak diperlukan; (2) Seiton, yaitu mengatur semua barang yang tersisa setelah seiri secara teratur; (3) Seiso, yaitu menjaga kebersihan mesin dan lingkungan kerja; (4) Seiketsu, yaitu memperluas konsep kebersihan untuk diri sendiri; dan (5) Shitsuke, yaitu membangun disiplin diri (Imai, 2012).

Robbins (2009) mengemukakan bahwa keterlibatan kerja sebagai proses partisipatif yang menggunakan seluruh kapasitas dari karyawan dan dirancang untuk mendorong peningkatan komitmen bagi suksesnya suatu organisasi. Keterlibatan kerja merupakan keterlibatan mental dan emosional orangorang di dalam situasi kelompok yang mendorong mereka untuk memberi kontribusi kepada tujuan kelompok dan berbagai tanggung jawab pencapaian tujuan itu (Davis \& Newstrom, 2009).

Luthans (2012) mendefinisikan bahwa keterlibatan kerja terjadi jika anggota organisasi menempatkan dirinya dalam peran fisik, kognitif, dan emosional selama kinerja peran (pekerjaan). Menurut Robbins (2009), indikator keterlibatan kerja yang terdiri dari: (1) partisipasi kerja; (2) keikutsertaan; dan, (3) kerjasama. Keterlibatan kerja termasuk keterlibatan mental dan emosional orangorang di dalam situasi kelompok yang mendorong mereka untuk memberikan kontribusi kepada tujuan kelompok dan berbagai tanggung jawab terhadap pencapaian tujuan.

Mathis dan Jackson (2011) mendefinisikan komitmen organisasi sebagai derajat yang mana karyawan percaya dan menerima tujuan-tujuan organisasi dan tidak akan meninggalkan organisasi. Robbins (2009) mendefinisikan komitmen organisasi sebagai suatu sikap yang merefleksikan perasaan suka atau tidak suka dari karyawan terhadap organisasi. Pandangan Bathaw dan Grant 
yang dikutip oleh Sopiah (2008) menyatakan bahwa komitmen organisasi sebagai bentuk keinginan karyawan untuk tetap mempertahankan keanggotaannya dalam organisasi dan bersedia melakukan usaha yang tinggi demi pencapaian tujuan organisasi.

Komitmen organisasi timbul secara bertahap dalam diri pribadi karyawan. Berawal dari kebutuhan pribadi terhadap organisasi, kemudian beranjak menjadi kebutuhan bersama, dan rasa memiliki dari para anggota (karyawan) terhadap organisasi. Beberapa indikator komitmen organisaasi, menurut Lincoln dan Bashaw yang dikutip Sopiah (2008) terdiri dari: (1) kemauan karyawan; (2) kesetiaan karyawan; serta, (3) kebanggaan karyawan pada organisasi. Faktor komitmen dalam organisasi menjadi satu hal yang dipandang penting, karena karyawan yang memiliki komitmen yang tinggi terhadap organisasi akan memiliki sikap yang profesional dan menjunjung tinggi nilai-nilai yang telah disepakati dalam sebuah organisasi.

Prestasi kerja adalah hasil kerja secara kualitas dan kuantitas yang dicapai oleh seorang pegawai dalam melaksanakan tugasnya sesuai dengan tanggung jawab yang diberikan kepadanya (Mangkunegara, 2014). Sedangkan Hasibuan (2013) mendefinisikan prestasi kerja sebagai suatu hasil kerja yang dicapai seseorang dalam melaksanakan tugas- tugas yang dibebankan kepadanya yang didasarkan atas kecakapan, pengalaman, dan kesungguhan serta waktu. Mangkunegara (2014) lebih lanjut mengemukakan indikator prestasi kerja yang terdiri dari: (1) kualitas; (2) kuantitas; (3) pelaksanaan tugas; dan, (4) tanggungjawab.

Prestasi kerja dapat diilhat sebagai hasil atau capaian mengenai kuantitas dan kualitas seorang karyawan terhadap pekerjaan yang diselesaikan oleh karyawan sesuai dengan ketepatan waktu terhadap jenis pekerjaan yang dikerjakannya. Prestasi kerja juga tertuju pada perwujudan kerja yang dilakukan oleh karyawan ataupun organisasi yang dipakai sebagai dasar penilaian atas karyawan atau organisasi kerja.

Berdasarkan hasil kajian teoritis, model kerangka konseptual pada penelitian ini dikembangkan seperti terlihat pada Gambar 1. Hipotesis yang dimunculkan berlandaskan gambar tersebut adalah: (1) budaya kaizen berpengaruh positif dan signifikan terhadap komitmen organisasi; (2) keterlibatan kerja berpengaruh positif dan signifikan terhadap komitmen organisasi; (3) budaya kaizen berpengaruh positif dan signifikan terhadap prestasi kerja karyawan; (4) keterlibatan kerja berpengaruh positif dan signifikan terhadap prestasi kerja karyawan; dan, (5) komitmen organisasi berpengaruh positif dan signifikan terhadap prestasi kerja karyawan.

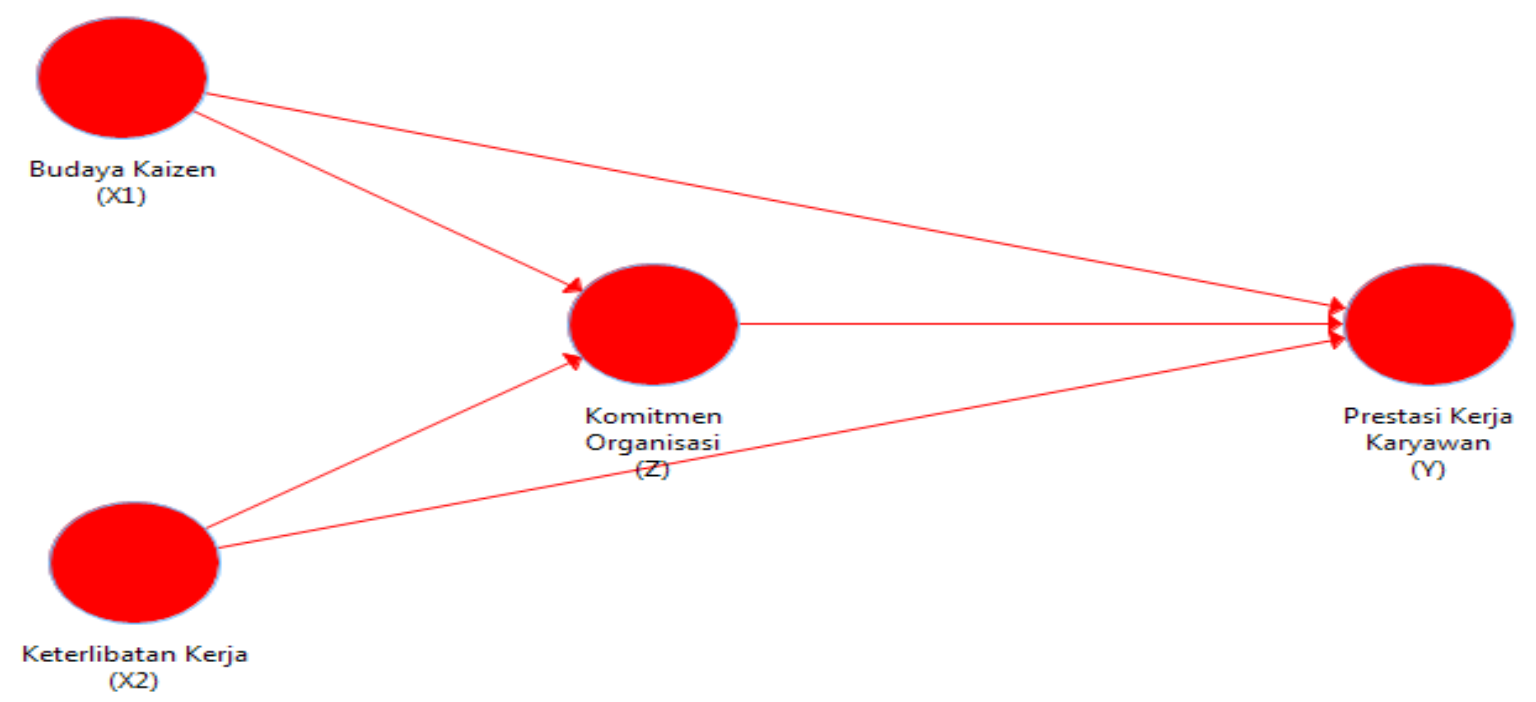

Sumber: Diolah peneliti, tahun 2018.

Gambar 1. Kerangka Teori 


\section{METODE PENELITIAN}

Penelitian ini dilaksanakan di PT. Gloria Jaya Sejahtera Medan yang beralamat di Jl. Gatot Subroto No.114, Medan. Jenis penelitian ini adalah deskriptif kuantitatif, yaitu penelitian yang mengukur kekuatan hubungan antara dua variabel atau lebih. Arikunto (2012) menyatakan penelitian deskriptif kuantitatif meliputi pengumpulan data untuk menguji hipotesis ataupun menjawab mengenai status terakhir dari subjek penelitian. Adapun sifat penelitian ini adalah penelitian penjelasan (deskriptif eksplanatori).

Populasi adalah wilayah generalisasi yang terdiri atas objek atau subjek yang mempunyai kualitas dan karakteristik kemudian ditarik kesimpulan (Sugiyono, 2011). Populasi dalam penelitian ini adalah seluruh karyawan yang ada pada PT. Gloria Jaya Sejahtera Medan yang berjumlah 40 orang karyawan. Selanjutnya, menurut Sugiyono (2011), sampel adalah sebagian dari jumlah dan karakteristik yang dimiliki oleh populasi. Teknik pengambilan sampel yang digunakan dalam penelitian ini adalah sensus, yaitu mengambil sampel dari seluruh populasi (sampel jenuh) sebanyak 40 orang karyawan.

Sumber data yang digunakan dalam penelitian ini adalah data primer, yaitu data yang diperoleh atau dikumpulkan secara langsung dari sumber datanya. Data primer dikumpulkan melalui wawancara dan kuesioner yang diberikan kepada responden yang dijadikan sampel. Penelitian ini menggunakan survey untuk mendapatkan data yang diperlukan.

\section{Tabel 1. Skala Likert}

\begin{tabular}{clc}
\hline No & \multicolumn{1}{c}{ Jawaban } & Skor \\
\hline 1 & Sangat Setuju (SS) & 5 \\
2 & Setuju (S) & 4 \\
3 & Kurang Setuju (KS) & 3 \\
4 & Tidak Setuju (TS) & 2 \\
5 & Sangat Tidak Setuju (STS) & 1
\end{tabular}

Sumber: Sugiyono, 2011.

Pengukuran penelitian ini menggunakan skala Likert, yang digunakan untuk mengukur sikap, pendapat, dan persepsi seseorang atau sekelompok orang tentang fenomena sosial
(Sugiyono, 2011). Rentang skala Likert yang digunakan ditunjukkan dalam Tabel 1.

Untuk mengukur kehandalan instrumen penelitian ini, maka dilakukan uji validitas dan reliabilitas. Uji validitas bertujuan untuk mengukur sah/valid atau tidaknya suatu kuesioner (Maholtra, 2009). Menurut Ghozali (2006), suatu kuesioner dikatakan valid jika nilai loading factor variabel lebih besar dari 0,5 (0,5 > Sig).

Uji reliabilitas adalah indeks yang menunjukkan suatu kuesioner dapat dipercaya atau tidak (Ghozali, 2006). Suatu kuesioner dikatakan reliabel atau handal jika jawaban seseroang terhadap pernyataan adalah konsisten atau stabil dari waktu ke waktu. Variabel dikatakan reliabel jika memberikan nilai Cronbach alpha $(\alpha)$ lebih besar daripada 0,6 . Untuk teknik analisis data menggunakan SEM (Stuctural Equation Modelling) dengan program SmartPLS (Partial Least Square) yang memberikan gambaran jelas terkait berhubungan antara konstrak penelitian (Ghozali \& Latan, 2015).

\section{HASIL ANALISIS \\ Uji Validitas dan Reliabilitas}

Hasil uji validitas pada penelitian ini dapat ditunjukkan dalam Tabel 2, berdasarkan teknik uji validitas convergent validitymeasurement model (meliputi: budaya kaizen $\left(\mathrm{X}_{1}\right)$; keterlibatan kerja $\left(\mathrm{X}_{2}\right)$; komitmen organisasi (Z); dan prestasi kerja (Y)). Dari Tabel 2, yaitu hasil uji validitas convergent validity. diketahui bahwa semua pernyataan yang diajukan dalam kuesioner (P1-P15) memiliki derajat convergent validity yang baik atau valid, karena nilai loading factor variabel lebih besar dari $0,5 \quad(0,5>\mathrm{Sig})$. Semakin tinggi nilai loading factor pada setiap konstrak menandakan semakin tinggi kontribusi indikator tersebut pada konstruk.

Berikutnya, hasil uji reliabilitas tentang variabel-variabel independen yang meliputi budaya kaizen $\left(\mathrm{X}_{1}\right)$, keterlibatan kerja $\left(\mathrm{X}_{2}\right)$, komitmen organisasi $(\mathrm{Z})$ dan prestasi kerja (Y), dirangkum ke dalam Tabel 3. Sebuah instrument penelitian dikatakan reliabel apabila memiliki nilai composite reliability diatas 0,70 . 
Tabel 2. Hasil Convergent Validity

\begin{tabular}{cccccccc}
\hline \multicolumn{2}{c}{ Budaya Kaizen $\left(\mathrm{X}_{1}\right)$} & \multicolumn{2}{c}{ Keterlibatan Kerja $\left(\mathrm{X}_{2}\right)$} & \multicolumn{2}{c}{ Komitmen Organisasi $(\mathrm{Z})$} & \multicolumn{2}{c}{ Prestasi Kerja $(\mathrm{Y})$} \\
\hline P1 & 0,933 & P6 & 0,852 & P9 & 0,841 & P12 & 0,603 \\
P2 & 0,925 & P7 & 0,940 & P10 & 0,696 & P13 & 0,879 \\
P3 & 0,867 & P8 & 0,897 & P11 & 0,859 & P14 & 0,944 \\
P4 & 0,899 & & & & & P15 & 0,934 \\
P5 & 0,826 & & & & & & \\
\hline
\end{tabular}

Sumber: Data primer (diolah), tahun 2018

Tabel 3. Hasil Uji Reliabilitas

\begin{tabular}{lcc}
\hline & Composite Reliability & Cronbach 's Alpha \\
\hline Budaya Kaizen $\left(\mathrm{X}_{1}\right)$ & 0,950 & 0,935 \\
Keterlibatan Kerja $\left(\mathrm{X}_{2}\right)$ & 0,925 & 0,878 \\
Komitmen Organisasi $(\mathrm{Z})$ & 0,843 & 0,718 \\
Prestasi Kerja Karyawan $(\mathrm{Y})$ & 0,893 & 0,836 \\
\hline
\end{tabular}

Sumber: Data primer (diolah), tahun 2018.

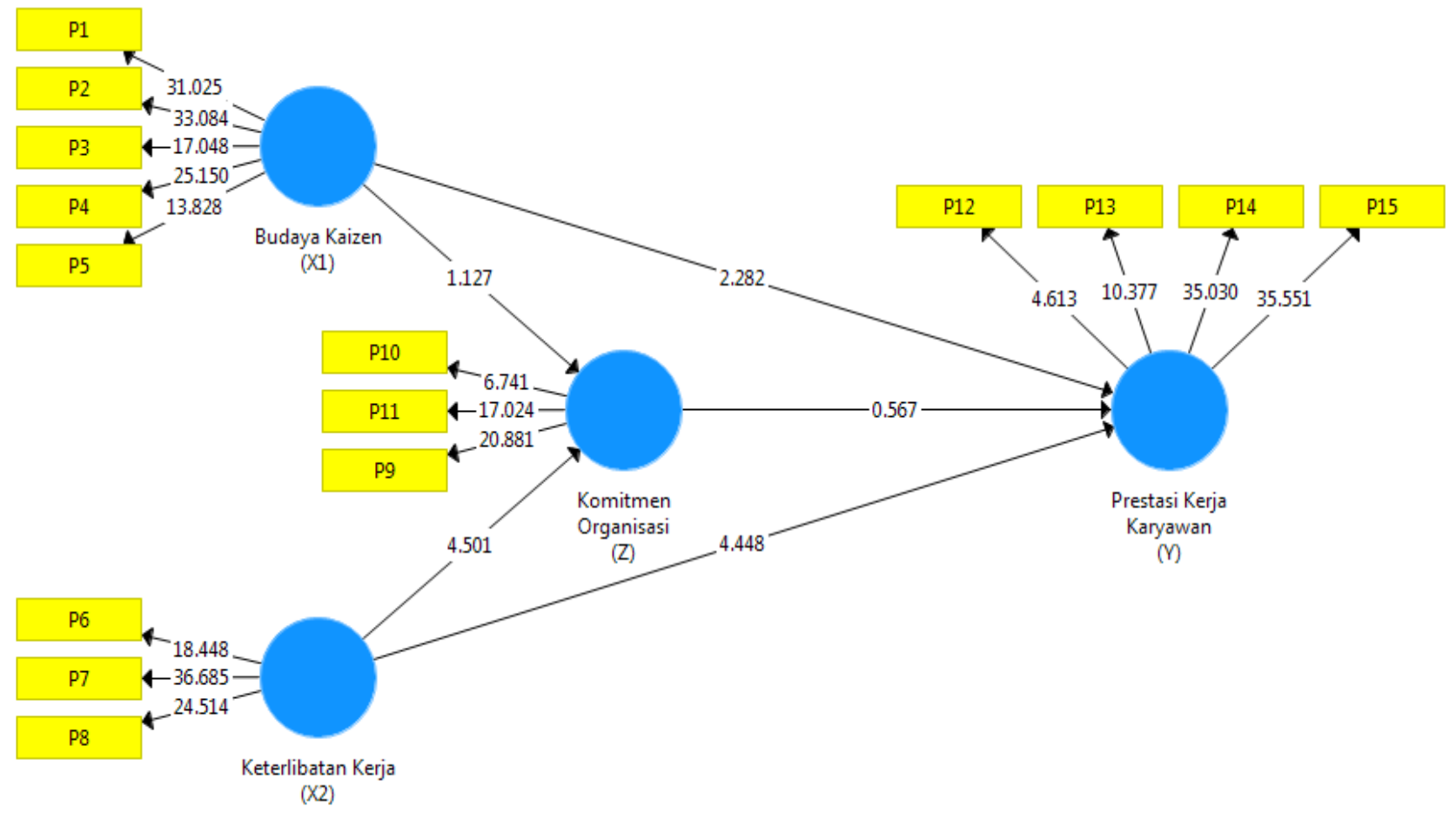

Sumber: Diolah peneliti, tahun 2018.

\section{Gambar 2. Model Signifikan}

Dari Tabel 3, terlihat bahwa nilai composite reliability untuk setiap variabel budaya kaizen $(0,950)$, keterlibatan kerja $(0,925)$, komitmen organisasi $(0,843)$, dan prestasi kerja karyawan $(0,893)$ adalah berada di atas 0,70. Begitu pula, untuk nilai Cronbach's alpha, semua konstruk memiliki nilai di atas 0,60. Dengan demikian, dapat disimpulkan bahwa instrumen penelitian yang digunakan memiliki reliabilitas yang baik. 
Tabel 4. Average Variance Extracted (AVE)

\begin{tabular}{lc}
\hline & AVE \\
\hline Budaya Kaizen $\left(\mathrm{X}_{1}\right)$ & 0,794 \\
Keterlibatan Kerja $\left(\mathrm{X}_{2}\right)$ & 0,805 \\
Komitmen Organisasi $(\mathrm{Z})$ & 0,643 \\
Prestasi Kerja Karyawan(Y) & 0,725 \\
\hline
\end{tabular}

Sumber: Data primer (diolah), tahun 2018

Untuk menilai discriminant validity adalah dengan membandingkan akar kuadrat dari Average Variance Extracted (AVE) untuk setiap konstruk dengan konstruk lainnya dalam model. Model mempunyai discriminant validity yang cukup jika nilai akar dari AVE untuk setiap konstruk lebih besar dari korelasi antara konstruk dan konstruk lainnya dalam model. Berdasarkan output yang terangkum dalam Tabel 4, nilai AVE adalah lebih besar dari 0,50. Dengan demikian dinyatakan bahwa semua konstruk memiliki reliabilitas yang baik sehingga model tersebut fit dengan data yang ada.

\section{Uji Hipotesis}

Uji hipotesis dilakukan menggunakan software SmartPLS. Uji yang dilakukan adalah evaluasi inner model dan uji $t$ untuk menjawab lima hipotesis yang dikemukakan. Hasil uji $t$ atau uji parsial ditunjukkan pada Gambar 2.

Selanjutnya, pengujian tentang derajat signifikansi atas model dilakukan dengan melihat nilai $R$-Square yang merupakan uji goodnees-fit model. Hasil uji ditunjukkan dalam Tabel 5.

Tabel 5. Nilai R-Square

\begin{tabular}{lc}
\hline & $R$-Square \\
\hline Komitmen Organisasi (Z) & 0,804 \\
Prestasi Kerja Karyawan(Y) & 0,888 \\
\hline
\end{tabular}

Sumber: Data primer (diolah), tahun 2018

Dari Tabel 5, nilai $R$-Square diketahui bahwa masing-masing variabel Komitmen Organisasi (Z) dan variabel Prestasi Kerja Karyawan (Y) dapat dijelaskan oleh kedua variabel independen, yaitu Budaya Kaizen $\left(\mathrm{X}_{1}\right)$, dan Keterlibatan Kerja $\left(\mathrm{X}_{2}\right)$, sebesar $80,4 \%$ dan $88,8 \%$. Sedangkan besaran sisanya dijelaskan oleh variabel-variabel lain yang tidak dimasukkan dalam model penelitian ini.

Berikutnya dilakukan uji kesesuaian model atau uji goodness of fit menggunakan persamaan Q-square. Hasil perhitungan adalah sebagai berikut:

$$
\begin{aligned}
\mathrm{Q}^{2}= & 1-(1-\text { Komitmen Organisasi }) \mathrm{x} \\
& (1-\text { Prestasi Kerja Karyawan }) \\
= & 1-(1-0,804)(1-0,888) \\
= & 1-(0,196)(0,112) \\
= & 0,978 .
\end{aligned}
$$

Dengan demikian, nilai $\mathrm{Q}^{2}$ sebesar $0,978>0$ atau berarti model memiliki kesesuaian.

Pengujian hipotesis yang diajukan, dapat dilihat dari besarnya nilai $t$-statistik. Batas untuk menolak dan menerima hipotesis yang diajukan adalah $\pm 1,96$, dimana apabila nilai $t$ berada pada rentang nilai $-1,96$ dan 1,96 maka hipotesis akan ditolak, atau dengan kata lain menerima $\mathrm{H}_{0}$. Hasil uji hipotesis berdasarkan nilai Path Coefficients dirangkum dalam Tabel 6.

Berdasarkan Tabel 6 Path Coefficients dari hasil uji- $t$ dengan taraf nyata $(\alpha) 0,05$ diketahui bahwa pengaruh Budaya Kaizen $\left(X_{I}\right)$ terhadap Komitmen Organisasi (Z) memiliki nilai koefisien parameter sebesar 0,191 dan nilai $t$-statistik sebesar 1,127 lebih kecil dari nilai t-tabel $(1,96)$; pengaruh Keterlibatan Kerja $\left(\mathrm{X}_{2}\right)$ terhadap Komitmen Organisasi (Z) memiliki nilai koefisien parameter sebesar 0,722 dan nilai t-statistik sebesar 4,501 lebih besar dari nilai t-tabel $(1,96)$; pengaruh Budaya Kaizen $\left(\mathrm{X}_{1}\right)$ terhadap Prestasi Kerja Karyawan (Y) memiliki nilai koefisien parameter sebesar 0,277 dan nilai $t$-statistik sebesar 2,282 lebih besar dari nilai t-tabel $(1,96)$; pengaruh Keterlibatan Kerja $\left(\mathrm{X}_{2}\right)$ terhadap Prestasi Kerja Karyawan (Y) memiliki nilai koefisien parameter sebesar 0,621 dan nilai t-statistik sebesar 4,448 lebih besar dari nilai t-tabel $(1,96)$; pengaruh Komitmen Organisasi $(Z)$ terhadap Prestasi Kerja Karyawan (Y) memiliki nilai koefisien parameter sebesar 0,072 dan nilai $t$ statistik sebesar 0,567 lebih kecil dari nilai $t$ tabel $(1,96)$. 
Tabel 5. Hasil Path Coefficients

\begin{tabular}{lcc}
\hline & Original Sample $(\mathrm{O})$ & t Statistics $(\mid \mathrm{O} / \mathrm{STDEV})$ \\
\hline Budaya Kaizen $\left(\mathrm{X}_{1}\right)$-> Komitmen Organisasi $(\mathrm{Z})$ & 0,191 & 1,127 \\
Keterlibatan Kerja $\left(\mathrm{X}_{2}\right)$-> Komitmen Organisasi $(\mathrm{Z})$ & 0,722 & 4,501 \\
Budaya Kaizen $\left(\mathrm{X}_{1}\right)$-> Prestasi Kerja Karyawan (Y) & 0,277 & 2,282 \\
Keterlibatan Kerja $\left(\mathrm{X}_{2}\right)$-> Prestasi Kerja Karyawan (Y) & 0,621 & 4,448 \\
Komitmen Organisasi $(\mathrm{Z})$-> Prestasi Kerja Karyawan (Y) & 0,072 & 0,567 \\
\hline
\end{tabular}

Sumber: Data primer (diolah), tahun 2018.

Pengujian hipotesis yang diajukan, dapat dilihat dari besarnya nilai t-statistik. Batas untuk menolak dan menerima hipotesis yang diajukan adalah $\pm 1,96$, dimana apabila nilai $t$ berada pada rentang nilai $-1,96$ dan 1,96 maka hipotesis akan ditolak, atau dengan kata lain menerima $\mathrm{H}_{0}$. Hasil uji hipotesis berdasarkan nilai Path Coefficients dirangkum dalam Tabel 6.

Berdasarkan Tabel 6 Path Coefficients dari hasil uji- $t$ dengan taraf nyata $(\alpha) 0,05$ diketahui bahwa pengaruh Budaya Kaizen $\left(X_{1}\right)$ terhadap Komitmen Organisasi (Z) memiliki nilai koefisien parameter sebesar 0,191 dan nilai $t$-statistik sebesar 1,127 lebih kecil dari nilai t-tabel $(1,96)$; pengaruh Keterlibatan Kerja $\left(\mathrm{X}_{2}\right)$ terhadap Komitmen Organisasi (Z) memiliki nilai koefisien parameter sebesar 0,722 dan nilai t-statistik sebesar 4,501 lebih besar dari nilai t-tabel $(1,96)$; pengaruh Budaya Kaizen $\left(\mathrm{X}_{1}\right)$ terhadap Prestasi Kerja Karyawan (Y) memiliki nilai koefisien parameter sebesar 0,277 dan nilai $t$-statistik sebesar 2,282 lebih besar dari nilai t-tabel $(1,96)$; pengaruh Keterlibatan Kerja $\left(\mathrm{X}_{2}\right)$ terhadap Prestasi Kerja Karyawan (Y) memiliki nilai koefisien parameter sebesar 0,621 dan nilai t-statistik sebesar 4,448 lebih besar dari nilai t-tabel $(1,96)$; pengaruh Komitmen Organisasi $(Z)$ terhadap Prestasi Kerja Karyawan (Y) memiliki nilai koefisien parameter sebesar 0,072 dan nilai $t$ statistik sebesar 0,567 lebih kecil dari nilai $t$ tabel $(1,96)$.

Berdasarkan Tabel 6 juga diperoleh bahwa variabel Komitmen Organisasi (Z) -> Prestasi Kerja Karyawan (Y) memiliki pengaruh yang rendah dengan nilai $t$-statistik sebesar 0,567 dibanding dengan pengaruh variabel lain. Hal ini menunjukkan bahwa
Komitmen Organisasi (Z) memperlemah hubungan terhadap Prestasi Kerja Karyawan (Y). Pengaruh variabel yang paling dominan adalah Keterlibatan Kerja $\left(\mathrm{X}_{2}\right)$-> Komitmen Organisasi (Z) dengan nilai $t$-statistik sebesar 4,501. Hal ini menunjukkan bahwa Keterlibatan Kerja $\left(\mathrm{X}_{2}\right)$ memiliki hubungan yang kuat terhadap Komitmen Organisasi (Z).

Untuk pengaruh langsung (Direct Effect atau DE) diperoleh: (a) Pengaruh Budaya Kaizen $\left(\mathrm{X}_{1}\right)$-> Komitmen Organisasi (Z) sebesar 0,191; (b) Pengaruh Keterlibatan Kerja $\left(\mathrm{X}_{2}\right) \rightarrow$ Komitmen Organisasi (Z) sebesar 0,722; (c) Pengaruh Budaya Kaizen $\left(\mathrm{X}_{1}\right)$-> Prestasi Kerja Karyawan (Y) sebesar 0,277; (d) Pengaruh Keterlibatan Kerja $\left(\mathrm{X}_{2}\right)$-> Prestasi Kerja Karyawan (Y) sebesar 0,621; dan, (e) Pengaruh Komitmen Organisasi (Z)-> Prestasi Kerja Karyawan (Y) sebesar 0,072.

Untuk pengaruh tidak langsung (Indirect Effect atau IE) diperoleh Pengaruh Budaya Kaizen $\left(\mathrm{X}_{1}\right)$, Keterlibatan Kerja $\left(\mathrm{X}_{2}\right)$ melalui Komitmen Organisasi $(Z)$ sebesar 0,191 x $0,722 \times 0,277 \times 0,621$ sama dengan 0,02 .

Implikasi manajerial berdasarkan hasilhasil penelitian ini adalah bahwa PT. Gloria Jaya Sejahtera Medan harus memahami kebutuhan dan keinginan karyawan, untuk kemudian berusaha untuk memenuhinya. Hal ini dilakukan untuk mengetahui komitmen karyawan terhadap perusahaan. Budaya Kaizen dapat dijadikan sebagai acuan untuk meningkatkan pengelolaan sistem manajemen, dan standar operasional terhadap pencapaian tujuan perusahaan. Keterlibatan kerja para karyawan juga perlu ditingkatkan dengan cara perusahaan memberi kontribusi penuh kepada karyawan sesuai dengan kebijakan yang tepat, agar karyawan lebih partisipatif dalam bekerja, dan memiliki kerjasama yang baik untuk mencapai hasil kerja secara maksimal. 


\section{KESIMPULAN}

Berdasarkan hasil pembahasan dalam penelitian yang dilakukan pada PT. Gloria Jaya Sejahtera Medan, maka beberapa kesimpulan yang diperoleh adalah: (1) budaya kaizen berpengaruh positif dan tidak signifikan terhadap komitmen organisasi; (2) keterlibatan kerja berpengaruh positif dan signifikan terhadap komitmen organisasi; (3) budaya kaizen berpengaruh positif dan signifikan terhadap prestasi kerja karyawan; (4) keterlibatan kerja berpengaruh positif dan signifikan terhadap prestasi kerja karyawan; serta, (5) komitmen organisasi berpengaruh positif dan tidak signifikan terhadap prestasi kerja karyawan.

Agenda penelitian selanjutnya perlu dilakukan penelitian-penelitian sejenis untuk tipe perusahaan lain yang belum tergambarkan dan mengamati kompetensi SDM, pengalaman kerja dan loyalitas karyawan sebagai variabel yang dapat memperkuat hubungan terhadap prestasi kerja karyawan.

\section{DAFTAR PUSTAKA}

Arikunto, S. 2012. Prosedur Penelitian Suatu Pendekatan Praktek. Yogyakarta: Rineka Cipta.

Davis, K. dan Newstrom, J.W. 2009. Perilaku dalam Organisasi. Jilid 1. Jakarta: Erlangga.

Ghozali, I. 2006. Aplikasi Analisis Multivariate dengan program SPSS. Semarang: Badan Penerbit Universitas Diponegoro.

Ghozali, I. dan Latan, H. 2015. Partial Least Square: Konsep, Teknik dan Aplikasi menggunakan Program SmartPLS 3.0. Semarang: Badan Penerbit Universitas Diponegoro.
Hasibuan, M.S.P. 2013. Manajemen Sumber

Daya Manusia. Jakarta: Bumi Aksara.

Imai, M. 2012. Gemba Kaizen. A Commonsense Approach to a Continuous Improvement Strategy. New York: McGraw-Hill Companies, Inc.

Luthans, F. 2012. Perilaku Organisasi. Yogyakarta: Penerbit Andi.

Malhotra, N.K. 2009, Basic Marketing Research: A Decision-Making Approach. Third Edition. Upper Saddle River, New Jersey: PrenticeHall, Pearson Education Inc.

Mangkunegara, A.A.P. 2014. Manajemen

Sumber Daya Manusia Perusahaan.

Bandung: Remaja Rosdakarya.

Mathis, R.L. dan Jackson, J.H. 2011. Manajemen Sumber Daya Manusia.

Edisi Sepuluh. Jakarta: Salemba Empat.

McLoughlin, C. dan Toshihiko, M. 2018. True Kaizen Management's Role in Improving Work Climate and Culture. New York: CRC Press Taylor \& Francis Group.

Robbins, S.P. 2009. Perilaku Organisasi. Jakarta: Salemba Empat

Robbins, S.P. dan Coulter, M. 2010. Manajemen. Edisi Kesepuluh. Jakarta: Erlangga.

Sugiyono. 2011. Metode Penelitian Kuantitatif, Kualitatif dan R\&D. Bandung: Afabeta.

Syamsuri, A.R. 2012. Analisis Pengaruh Pendidikan, Pengawasan Kerja dan Disiplin terhadap Kinerja Pegawai Dinas Pendidikan Kabupaten Mandailing Natal. Tesis. Tidak Dipublikasikan. Medan: Universitas Sumatera Utara. 